\title{
Tuberculous Epididymitis Mimicking a Testicular Tumour: A Case Report
}

\section{Testis Tümörünü Taklit Eden Tüberküloz Epididimit: Bir Olgu Sunumu}

\author{
Adem Altunkol1, Yalçın Evliyaoğlu1, Nevzat Can Şener1, Pelin Demirtürk2, Deniz Abat1, \\ Erbay Tümer1, Ercan Yeni3
}

1Adana Numune Teaching and Research Hospital, Clinic of Urology, Adana, Turkey

2Adana Numune Teaching and Research Hospital, Clinic of Pathology, Adana, Turkey

3 Harran University Faculty of Medicine, Department of Urology, Şanlıurfa, Turkey

\begin{abstract}
Tuberculosis is a disease that affects almost every organ. The diagnosis and treatment of primary genitourinary tuberculosis is cumbersome and often requires invasive procedures for diagnosis. It is mandatory to differentiate tuberculous epididymitis from other causes of intrascrotal diseases such as bacterial epididiymitis and tumors. We discussed a case of tuberculous epididymitis presenting with a scrotal mass, to emphasize that tuberculous should also be considered in the differential diagnosis, besides malignancy.
\end{abstract}

\section{Key Words}

Epididymitis, tuberculosis, tumor

\section{ÖZET}

Tüberküloz her organı etkileyebilen bir hastalıktır. Primer genitoüriner tüberkülozun tanı ve tedavisi zordur ve çoğunlukla tanı için invaziv girişimler gerekmektedir. Tüberküloz epididimitin, bakteriyel epididimit ve testis tümörü gibi diğer skrotum hastalıklarından ayırt edilmesi zorunludur. Skrotal kitle ile başvurup tüberküloz epididimit tespit edilen olguyu, ayırıcı tanıda malignitenin yanında aynı zamanda tüberkülozunda hatırlanması gerektiğini vurgulamak için burada tartıştık.

Anahtar Kelimeler

Epididimit, tüberküloz, tümör

\section{Introduction}

Genitourinary tuberculosis (GUTB) represents the second most common involvement of extrapulmonary tuberculosis after lymph node involvement (1). It is estimated that GUTB constitutes $30 \%$ of nonpulmonary tuberculosis, and it can cause diseases in retroperitoneum, adrenal gland, kidney, urinary collecting system, male genital system, and female pelvic organs (2). The kidney is generally the first affected genitourinary organ by tubercle bacillus. Microorganisms reach the epididymis via haematogenous route or directly from the prostate and seminal vesicle (3). However, it might be difficult to differentiate epididymo-orchitis from a testicular tumor (4). The current study aimed to present a case of tuberculous epididymitis, mimicking a testicular tumor, treated by orchiectomy.

\section{Case Report}

A 44-year-old male patient was admitted to our clinic with swelling of the right testicle, for the past four months. The patient received treatment for non-specific epididymo-orchitis at another center, but regression was not observed. On physical examination, the right testicle and epididymis were found to be hard and endured. The left testicle was normal, but the epididymis persisted. The patient history did not reveal any significant features. Biochemical and serological tests for brucellosis and tumor markers were negative. Scrotal ultrasonography (USG) showed a heterogeneous, hypoechoic mass measuring $26 \times 20 \mathrm{~mm}$ in diameter in the right testicular parenchyma, but it was not possible to differentiate between abscess and a solid mass. In addition, a peritesticular cystic mass measuring approximately $35 \times 20 \mathrm{~mm}$ in diameter, with a thick wall, and internal echogenicity was detected. Thus, the patient underwent magnetic resonance imaging (MRI) examination of the testicle and thoracic computed tomography (CT). MRI showed a $5 \times 3 \mathrm{~cm}$, paratesticular, space-occupying formation in the right scrotum, which sprang the testis, and had a thick capsule and dense fluid content (Figure 1). There was no evidence of any infection or metastasis on thoracic CT. This case was misdiagnosed as testicular tumor and radical orchiectomy 


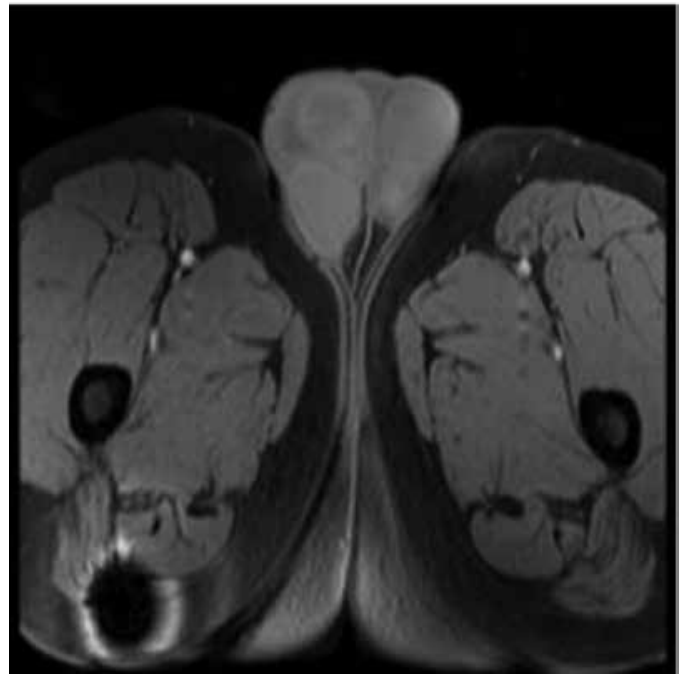

Figure 1. Scrotal magnetic resonance image of tuberculosis epididymitis

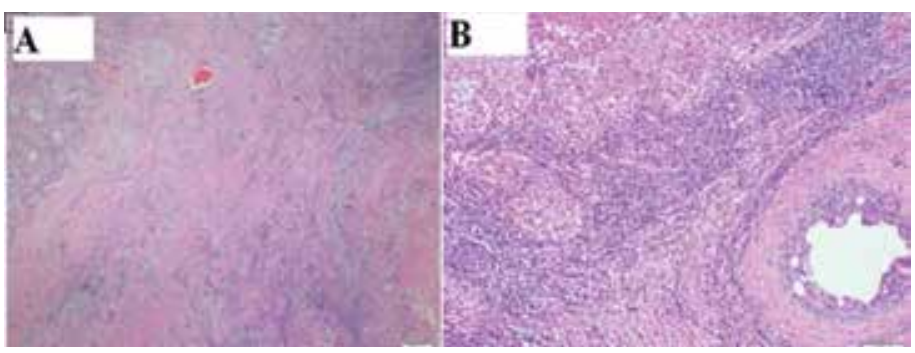

Figure 2. A: Granulomatous inflammation with caseous necrosis in testicular tissue and paratesticular $(H \& E, x 40)$. B: Granulomatous structures surrounding vas deferens $\left(H \& E_{1} \times 100\right)$

was performed. Examination of the frozen sections of the specimen revealed tuberculosis, therefore, the other testis was left intact.

The pathological examination of the specimen showed a $3 \times 2 \mathrm{~cm}$, irregularly circumscribed lesion in the epididymis and spermatic cord was attached to the testicle in the focal area, and contained yellow purulent material. There was no macroscopic abnormality on the testis. Microscopic examination showed granulomatous cells with caseous necrosis, and the patient was diagnosed with tuberculous epididymitis (Figures $2 \mathrm{~A}$ and $2 \mathrm{~B}$ ). According to the recommendation of the infectious diseases clinic, the patient was commenced on a sixmonth quadruple antituberculosis treatment (rifampicin, isoniazid, pyrazinamide, and ethambutol).

\section{Discussion}

The most frequent route of transmission for tubercle bacillus to genitourinary system is hematogenous spread. In addition, descending (from the upper urinary tract) and lymphatic and direct spread enables the bacilli to localize in this region. During the initial stage of infection, only involvement of epididymis is seen, and the disease spreads to the testicle on the same side as the stages advance (5). A history of tuberculosis is present in $70 \%$ of cases. The initial symptom is scrotal swelling associated with pain (40\%). This is followed by scrotal sinus (20\%), acute epididymo-orchitis (10\%), infertility (10\%), and hematospermia (5\%). Constitutional symptoms, such as fever and weight loss are generally not present. Tuberculous epididymitis is usually unilateral, and the incidence of bilateral cases is $12.5 \%$ (6).
In 50\% of GUTB cases, active tuberculosis can be detected in another part of the body (7).

Due to possible inflammatory reactions in the testicle in the acute phase, differentiating acute epididymo-orchitis and malignancies can be challenging (8). In the present case, we could not differentiate the lesion from malignancy based on physical examination and imaging techniques. Oncological principles were followed due to a suspicious testicular mass, and the patient underwent radical orchiectomy. In a study, it has been stated that Doppler USG findings were correlated with histopathological findings, and this method was useful in the differential diagnosis of tuberculous epididymitis and non-tuberculous epididymitis (7). Especially in patients with a previous history of pulmonary tuberculosis, the combined use of scrotal MRI and urinary polymerase chain reaction (PCR)-based assay for mycobacterial DNA is a valuable method in differential diagnosis of tuberculous epididymitis (9). The differential diagnosis of tuberculous epididymo-orchitis includes bacterial epididymoorchitis, sarcoidosis and testicular tumor. Sudden onset of testicular pain, dysuria, and high fever are seen in bacterial epididymo-orchitis. Doppler USG shows increased testicular blood flow (10). Sarcoidosis is rare in the genitourinary system, and the epididymis is affected more commonly compared to the testicles. USG shows bilateral, small, multiple lesions, and testicular lesions are hypoechoic. A testicular tumor is detected as a pain-free mass by the patients, and through routine examination by the physician. In rare cases, patients can be admitted with secondary acute pain resulting from a mass expanding to the inelastic tunica albugenia, which results from bleeding in the testis and extravasation of tumor vasculature. These patients usually have high levels of testicular tumor markers. On USG, they are seen as heterogeneous masses, together with non-seminomatous tumors, cysts, and calcifications. However, seminomas consist of homogeneous, hypoechoic, and sharp-circumscribed masses. Diffuse enlargement of the epididymis is a clue for infection, rather than malignancy. In testicular tumors, involvement of epididymis is usually present in advanced stage and epididymis is involved partially. Infertility is a rare and late symptom of GUTB. A direct obstruction by granulomatous masses in the epididymis or vas deferens, or deterioration or scarring of the normal anatomy results in infertility. Given that obstructive azospermia is the most common cause of tuberculosis-associated infertility, reproductive support will be needed for the majority of patients with sequel tuberculosis infertility who did not complete their treatment. Given that the testis is usually preserved in these cases, it is almost always possible to detect healthy testicular sperm that is suitable for fertilization $(11,12)$.

As a result, as well as malignancy, tuberculous epididymitis should be kept in mind for patients suffering from testicular swelling and do not respond to antibiotic treatment.

Ethics Committee Approval: Ethics committee approval was not obtained due to the study was a case report.

Informed Consent: All the patients gave written informed consent. Concept: Adem Altunkol, Deniz Abat

Design: Adem Altunkol, Ercan Yeni, Yalçın Evliyaoğlu

Data Collection or Processing: Nevzat Can Şener, Erbay Tümer

Analysis or Interpretation: Pelin Demirtürk, Ercan Yeni

Literature Search: Adem Altunkol, Erbay Tümer

Writing: Adem Altunkol 
Peer-review: Externally peer-reviewed.

Conflict of Interest: No conflict of interest was declared by the authors.

Financial Disclosure: The authors declared that this study has received no financial support.

\section{References}

1. Kapoor R, Ansari MS, Mandhani A, Gulia A. Clinical presentation and diagnostic approach in cases of genitourinary tuberculosis. Indian J Urol 2008;24:401-405.

2. Wise GJ, Marella VK. Genitourinary manifestations of tuberculosis. Urol Clin N Am 2003;30:111-121.

3. Çimen F, Saka D, Ünsal E, Önal M, Ceylan T, Atikcan Ş, Öğretensoy M. A Case of Isolated Tuberculous Epididymitis. Respiratory Diseases Journal 2013;24:79-81.

4. Shenoy VP, Viswanath S, D'Souza A, Bairy I, Thomas J. Isolated tuberculous epididymoorchitis: an unusual presentation of tuberculosis. J Infect Dev Ctries 2012;12;6:92-94
5. Yıldırım M, Güçlü E, Tekin A, Yıldırım Ü, Günal Ö. Tuberculous epididymitis: a case report and review of the literature. Düzce Medical Journal 2008;2:41-44.

6. Viswaroop BS, Kekre N, Gopalakrishnan G. Isolated tuberculous epididymitis: a review of forty cases. J Postgrad Med 2005;51:109-111.

7. Çiftçi $F$, Deniz Ö, Bozkanat $E_{1}$ Çermik $H_{1}$ Yüksekol I, Bilgiç $H$, Demirci N. Miliary Tuberculosis and Tuberculous Epididymitis: Case Report. Tuberk Toraks 2002;50:387-390.

8. Wolf JS Jr, McAninch JW. Tuberculousepididymo-orchitis. Diagnosis by fine needle aspiration. J Urol 1991;145:836-838.

9. Liu HY, Fu YT, Wu CJ, Sun GH. Tuberculous epididymitis: a case report and literature review. Asian J Androl 2005;7:329-332.

10. Palvica P, Barozzi L. Imaging of the acute scrotum. Eur Radiol 2001;1:220228.

11. Isen K, Bakır S. Isolated testicular tuberculosis mimicking a testicular tumor. Ege Journal of Medicine 2010;49:59-62.

12. Demers V, Pelsser V. "BCGitis": A rare case of tuberculous epididymoorchitis following intravesical Bacillus Calmette-Guérin therapy. J Radiol Case Rep 2012;6:16-21. 